\title{
Measurement of Vibration on The Alternator Due to The Influence of Rotation Speed
}

\author{
Subekti Subekti $^{\mathrm{a}^{*}}$, Hadi Pranoto ${ }^{\mathrm{a}}$, Muhammad Nurul Hidayat ${ }^{\mathrm{b}}$, Basuki Dwi Efendy $^{\mathrm{b}}$ \\ ${ }^{a}$ Department of Mechanical Engineering, Faculty of Engineering, Universitas Mercu Buana, Jakarta, Indonesia \\ ${ }^{b}$ PT. Astra Daihatsu Motor, Jakarta, Indonesia
}

\begin{abstract}
The alternator or dynamo ampere is a device that functions as a generator that produces alternating current (AC) and converts it to direct current (DC). Signs of damage that often occur due to damage to the Alternator are the smell of burning, squeaking, dim spotlights, indicator lights, malfunction of the battery, and the supply of electricity. These signs will cause the vehicle to stop in the middle of the trip the electricity supply is very lacking. This requires that preventive maintenance checks on the alternator are a must in the automotive world. In this paper we research measuring the vibration of the alternator due to the influence of rotation speed $(750 \mathrm{rpm}$ and $1800 \mathrm{rpm})$, to predict damage to the alternator of the Daihatsu Luxio vehicle. The results of this study indicate that at the rotational speed of $750 \mathrm{rpm}$ and $1800 \mathrm{rpm}$, were found $1 \mathrm{x} \mathrm{rpm}$ the condition of the vibration amplitude on the alternator is smaller than the alternator in poor condition, this is due to the presence of an unbalanced alternator. Also, vibration due to misalignment is obtained because it has characteristics, among others: vibrations with a frequency of 1xRPM and/or accompanied by a relatively large 2xRPM, and relatively high vibration in the axial direction.
\end{abstract}

Keywords: alternator; damage; vibration; unbalance; misalignment

DOI: $10.37869 /$ ijatec.v2i1.44

Received 16 March 2021; Accepted 29 March 2021; Available online 19 April 2021

(C) The Authors. Published by IRIS. This is an open access article under the CC BY-NC-SA license cc) (1) (3)

\section{Introduction}

Vehicles running on gasoline have a soft sound, and even tend to be less sound than diesel-fueled vehicles. However, if the gasoline engine has a rough sound symptom appearing from the combustion engine, it is even more extreme, like a diesel which is quite loud. This is caused by the presence of components such as a water pump, bearings in the cooling system, and the alternator, which cause a very large harsh noise [1]. In general, alternator noise is a combination of mechanical, aerodynamic, and electromagnetic systems. When the alternator is loaded with electrical loads the sound level increases [2]. Alternator damage is caused by damage to the bearings due to the unbalance of the shaft on the alternator. The detection of rolling bearing damage on the outer pass, inner passage, rolling elements, or combination damage is measured using a vibration signal, the resulting modulation signal is then carried out by the Envelope Analysis method [3]. Also, the measurement of the damage to the elements on rolling bearings can be done by measuring the vibration generated in the form of a frequency signal when the bearing rotates [4]. The damage that occurs to the bearing is included in the type of unbalance damage because it has a high amplitude at 1xRPM so that the bearing on the condensate pump needs to be replaced [5]. The method based on Principal Component Analysis (PCA) on centrifugal pumps makes it easy for operators to monitor pump conditions [6]. 
The alternator or dynamo ampere is a device that functions as a generator that produces alternating current (AC) and converts it to direct current (DC). This component also generates electrical energy which is filled in the battery, as shown in Figure 1. The charging system has 3 important components, namely the Accumulator, Alternator, and Regulator. This alternator functions together with the Accumulator to generate electricity when the engine is turned on. The result produced by the alternator is an AC voltage which is then converted into DC voltage. As a power generator, it utilizes the rotation of the engine, therefore the alternator requires a belt or belt. The belt functions to distribute the rotational motion of the car engine to rotate the alternator, this rotation is used by the alternator to generate electrical energy. In operation, the components inside the alternator move in rotation with a certain rotation. When the components move, there are forces of inertia and forces that come from the power transmission process. These forces will cause the component structure on the alternator to vibrate. In a well-designed alternator, the resulting vibration is lower, but if a long period of use will cause the amplitude of the vibration to be large, this will affect the condition of the components inside. The resulting vibration signal will have a spectrum frequency and certain vibrational characteristics. The effect of the vibrations that appear on the alternator components has a very large effect, which in turn will cause a harsh sound to appear.

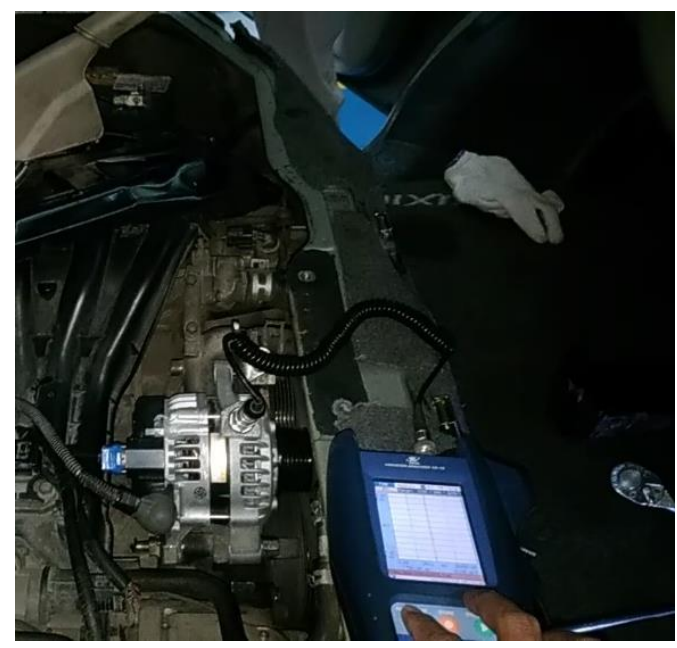

Figure 1. Alternator Daihatsu Luxio

Signs of damage that often occur due to damage to the Alternator are the smell of burning, squeaking, dim spotlights, indicator lights, malfunction of the battery, and the supply of electricity. These signs will cause the vehicle to stop in the middle of the trip the electricity supply is very lacking. This requires that preventive maintenance checks on the alternator are a must in the automotive world. Preliminary analysis of the relationship between the current exiting the alternator produces a noisy sound. this shows the fact that magnets occur due to design or assembly errors [7]. the relationship between rotation to housing and alternator structure can provide substantial benefits [8]. the magnitude of the vibration signal amplitude indicates the damage to the alternator. The vibration characteristics of the alternator indicate a fault that occurs, so that it can be distinguished from normal mode vibrations [9]. Analysis of the data on the alternator shows that there is an error in the diagnosis, which causes alternator failure based on the output voltage parameter [10].

Based on the above, in this paper we research measuring the vibration of the alternator due to the influence of rotation speed, to predict damage to the alternator of the Daihatsu Luxio vehicle. This is because the Daihatsu Luxio type of vehicle is widely used by the wider community, both for commercial vehicles and family vehicles. This can be seen where sales can reach 250 to 300 units per month. The excitation force comes from changes in the given rotation speed, the response that occurs is measured using a Vibration Analyzer model VA12 produced from Rion - Japan. Furthermore, the results of the measurement data were analyzed using MATLAB software.

Research on vibration testing in vehicles has been done a lot, such as checking the end-wall of a new engine that is damaged or not. The identification of damage to the tapper bearing was carried out by testing the FRF, the excitation force using a harmonic signal from a mobile phone [11]. Also, in detecting damage caused by cracks in gears, the frequency response function (FRF) method can be 
used [12]. The FRF method shows that below the first resonant frequency reflects the bearing stiffness, with this method can extract the stiffness coefficient from parallel and radial bearings [13], and tapered bearings provide a higher vibration amplitude than ball bearings [14],[15]. Vibration Testing in the Lab. Mercubuana University vibrations have been widely applied to both construction and vehicle systems. FRF testing is to determine the dynamic characteristics of a single-cylinder diesel engine [16] and a Sigra disc brake [17] to obtain global and local vibration modes. Also, the bump test method can be performed to determine the damage to the Sigra disc brake [18]. The vibration method is used in the production process to predict end mill damage on CNC machines [19]. In industrial equipment, a damage analysis of the screw compressor is carried out using a vibration test showing that there is damage to the screw shaft due to unbalance [20]. Meanwhile, electrical engineering is carried out by testing the vehicle actuator to predict damage by vibration testing with the Hilbert transform method [21]. FRF methods have been used to predict a structure, such as detecting damage [22], cracks [23], and dynamic characteristics of structures [24].

\section{Research Methodology}

To determine the damage to the alternator, this research was carried out by measuring the vibration by measuring the rotational speed. The rotation speed is carried out in two variations, namely 750 rpm and $1800 \mathrm{rpm}$ or around $12.5 \mathrm{~Hz}$ and $30 \mathrm{~Hz}$. Measurements are made in ideal or stationary vehicle conditions. The excitation force comes from the alternator rotation, then the amount of response that occurs is measured using a vibration analyzer by first placing the accelerometer sensor at the desired point on the alternator. The measured vibration response is carried out at six points, namely point B, C, E, and F, as shown in Figure 2.

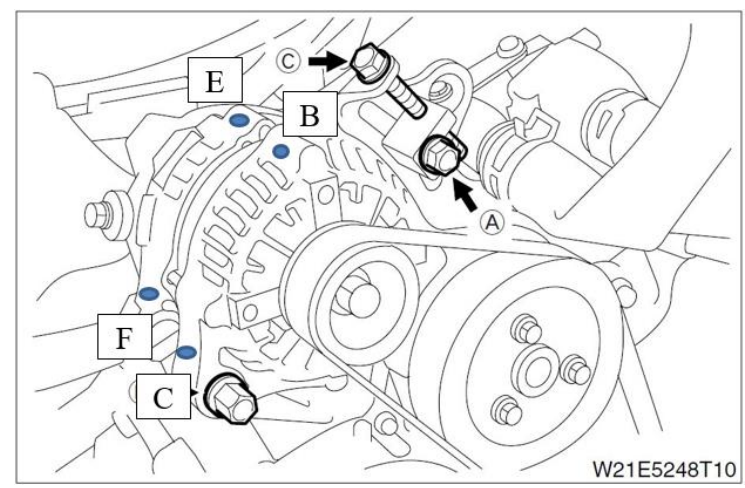

Figure 2. Position Sensor placement

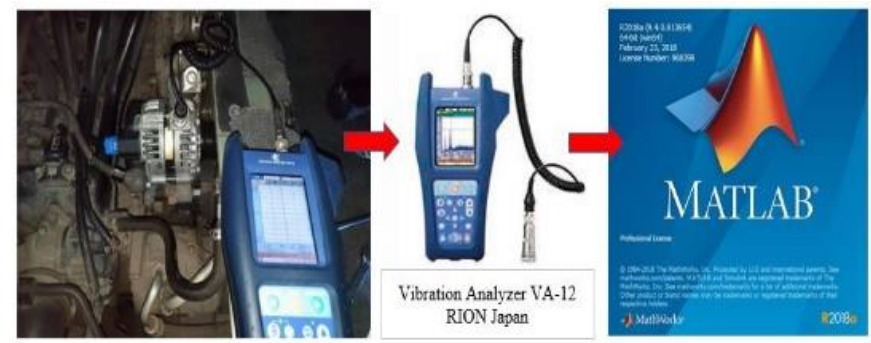

Figure 3. Set-up vibration measurement

The frequency range used in this study is $1-1000 \mathrm{~Hz}$, where the data collection and processing procedures can be seen in Figure 3. The data obtained from the measurement results are then analyzed using Matlab. The equipment used in the collection of vibration measurement data is as follows:

- The accelerometer, which is used is a piezoelectric accelerometer made by Rion Japan Corporation type CCLD type, PV-571. Accelerometer functions to measure vibration response.

- Frequency span $100 \mathrm{~Hz}$ with line analysis 1600 using linear function window.

- Actual Sensitivity Num 510 and actual sensitivity magnify x0.01. 


\section{Results and Discussion}

Before the vibration measurement is carried out, the vibration measuring instrument is adjusted where the amount of data to be taken is as much as 4096 data. The window type used for vibration analysis is the Hanning window. This is because the Hanning window has high accuracy for displaying amplitude compared to other window types. Furthermore, measurements are made at each point at each variation of rotational speed. Variations in rotational speed in this study, namely $750 \mathrm{rpm}$ and $1800 \mathrm{rpm}$.

In the measurement of vibration at a rotation speed of $750 \mathrm{rpm}$ or $12.5 \mathrm{~Hz}$, it is shown that the alternator conditions are not good or damaged, it is shown that at frequencies above 2xrpm, the alternator conditions are good, besides that the alternator conditions are not good at frequencies above 2 xrpm causing high noise and resonance. occurs, as shown in Figure 4 (a). Figure 4 (a) shows at $1 \mathrm{x} \mathrm{rpm}$ the condition of the vibration amplitude on the alternator is smaller than the alternator in poor condition, this is due to the presence of an unbalanced alternator. Also, vibration due to misalignment is obtained because it has characteristics, among others: vibrations with a frequency of 1 xRPM and/or accompanied by a relatively large 2 XRPM, and relatively high vibration in the axial direction.

The Power Spectral Density (PSD) analysis shows clearly that the alternator in a damaged condition has a frequency shift that occurs compared to the alternator in good condition, as shown in Figure 4 (b).

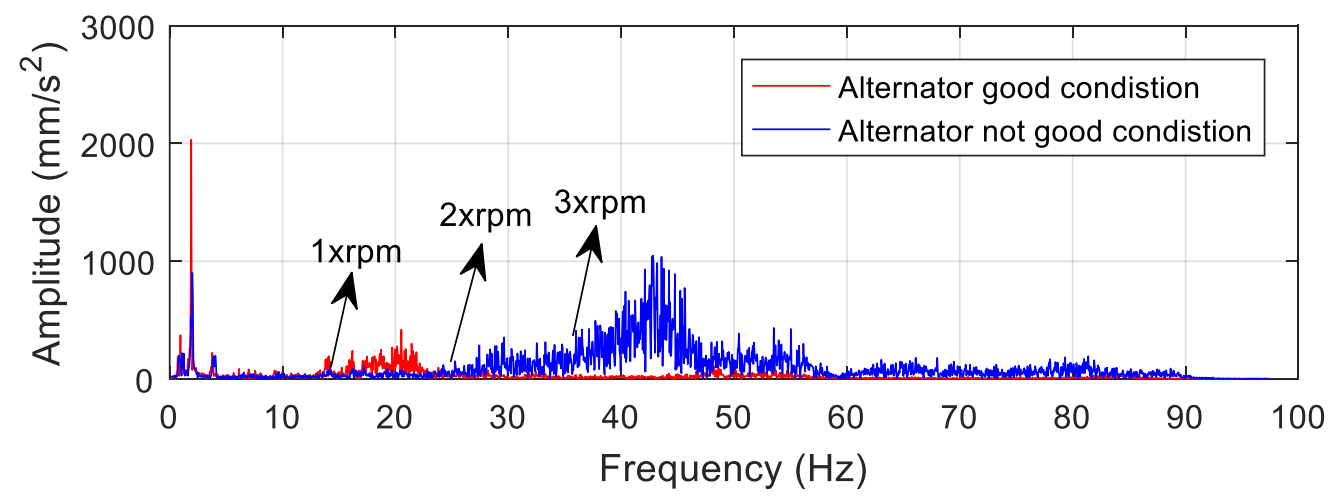

(a) Fast Fourier Transform Analysis

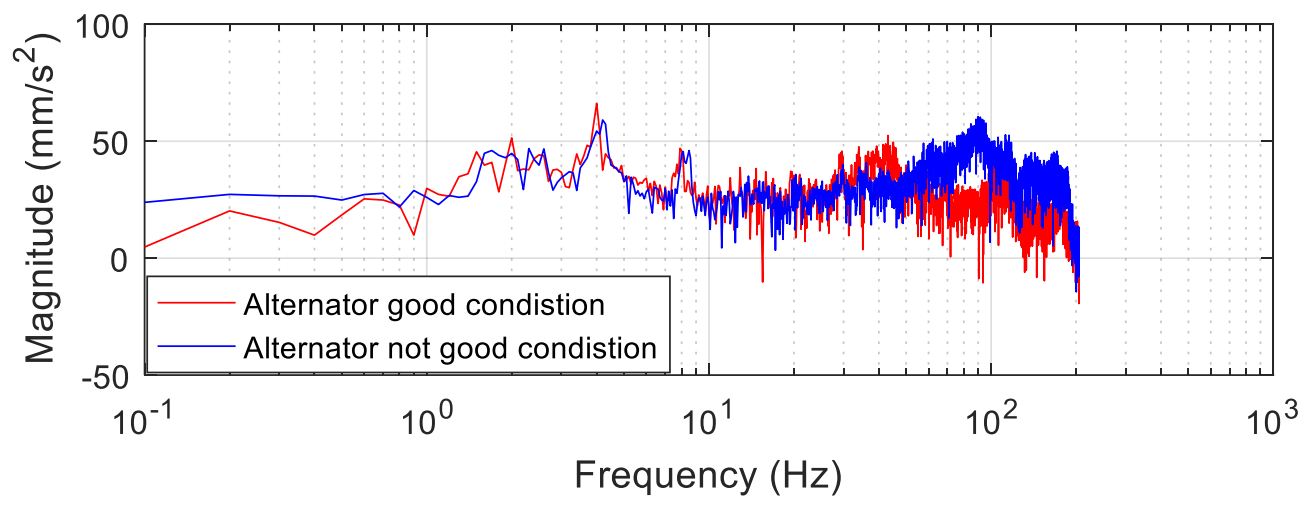

(b) PSD Analysis

Figure 4. Vibration analysis with a rotation speed of $750 \mathrm{rpm}$ at point $\mathrm{E}$

At the rotation speed of $1800 \mathrm{rpm}$, the noise produced is lower than the rotation speed of 750 rpm. This shows that the faster the alternator rotation can reduce the resulting noise. The damage due to misalignment and imbalance in the alternator is obvious. This is because the resonance that occurs is reduced with less noise. At the rotating speed of $1800 \mathrm{rpm}$, an imbalance occurs in the rotor. Rotor imbalance can be interpreted as an unbalanced mass distribution at the center of rotation of the rotor and this is the most common problem in alternators, where vibrations with a frequency of 1xRPM and/or accompanied by a relatively large 2xRPM. Also, at $1800 \mathrm{rpm}$ the alternator experienced shaft misalignment. Shaft misalignment is the most common cause of alternator due to 
vibration after imbalance, which causes an increase in dynamic load and accelerates the breakdown of the alternator wherein the misalignment provides fundamental harmonics at $2 \mathrm{x} \mathrm{rpm}$, as shown in Figure 5(a).

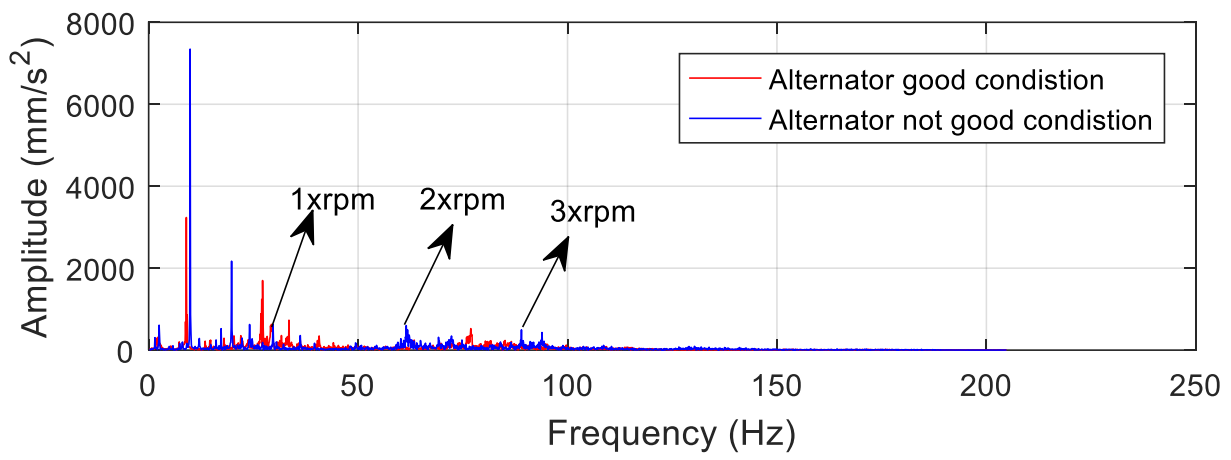

(a) Fast Fourier Transform Analysis

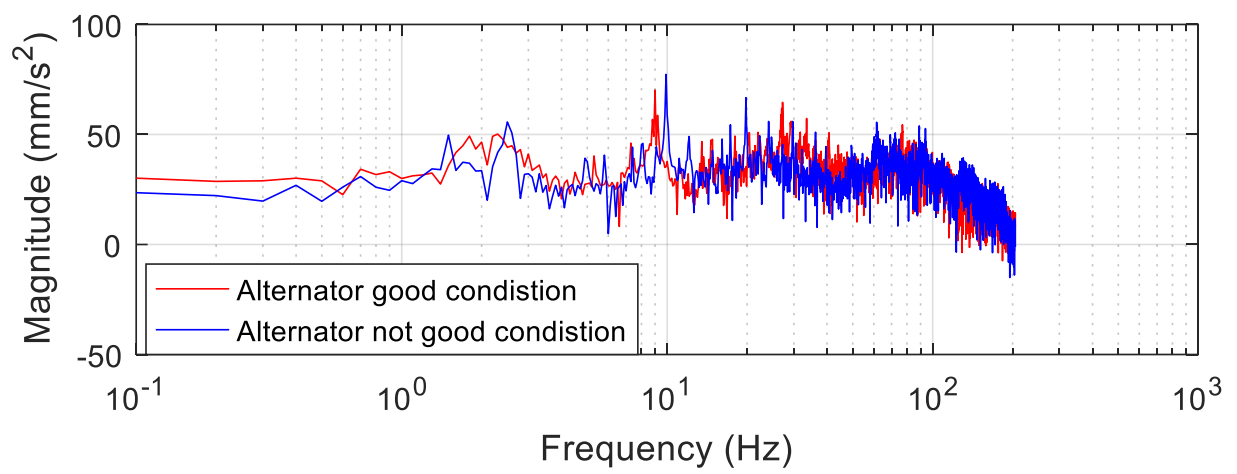

(b) PSD Analysis

Figure 5. Vibration analysis with a rotation speed of $1800 \mathrm{rpm}$ at point $\mathrm{E}$

In Figure 5, it is shown that the damaged alternator has experienced a frequency shift from the alternator in good condition. Also, the emergence of new frequencies is generated in certain states and stages of deterioration, where the spectral data shows the sub-harmonic multiplication of 1 / 2xRPM.

Also, the occurrence of mechanical looseness on the rotating parts is not properly installed. the number of running speed harmonics will dominate the spectral data. so, it is very important to detect damage to the alternator early through vibration monitoring techniques. With the vibration analysis, it is possible that three conditions such as unbalance, misalignment, and mechanism looseness can be identified early to prevent components from being damaged.

\section{Conclusions}

1x rpm the condition of the vibration amplitude on the alternator is smaller than the alternator in poor condition, this is due to the presence of an unbalanced alternator. Also, vibration due to misalignment is obtained because it has characteristics, among others: vibrations with a frequency of 1 xRPM and/or accompanied by a relatively large 2xRPM, and relatively high vibration in the axial direction.

\section{References}

[1] D. Apriliananda, Kompas "Suara mesin bensin mirip diesel? Kenali penyebabnya!," Https://Otomotif.Kompas.Com/Read/2015/04/22/134316815/Suara.Mesin.Bensin.Mirip.Diese l.Kenali.Penyebabnya. Accessed: 27 Juli 2020.

[2] B. Prasanth, S. Wagh, S., and D. Hudson, "Alternator Whining Noise-A Sound Quality Concern In Passenger Car," Sae Technical Paper 2011-26-0018, 2011, https://Doi.Org/10.4271/2011-26$\underline{0018 .}$ 
[3] R. Maladzi, T. Prahasto, A. Widodo, "Analisis Kerusakan Bantalan Gelinding Dengan Variasi Kecepatan Putar Berdasarkan Pola Getaran Menggunakan Metoda Envelope Analysis", Jurnal Teknik Mesin Universitas Diponegoro, V. 5, N. 1, Pp. 32-41, Jan. 2017.

[4] M. Rivai, N. Pranandita, "Analisa Kerusakan Bantalan Bola (Ball Bearing) Berdasarkan Signal Getaran", Manutech, V. 10, N. 2, Pp. 41-46, 2018.

[5] G.Z. Abidin, I.W. Sujana, "Deteksi Kerusakan Bearing Pada Condensate Pump Dengan Analisis Sinyal Vibrasi", Jurnal Flywheel, V. 8, N. 1, Pp. 60-67, 2017.

[6] B.P. Kamiel, N. Prastomo, B. Riyanta, "Ekstraksi Parameter Statistik Domain Waktu Dan Domain Frekuensi Untuk Mendeteksi Kavitasi Pada Pompa Sentrifugal Berbasis Principal Component Analysis (Pca)", Rekayasa Mesin, V. 10, N. 2, Pp. 165-176, Aug. 2019.

[7] W. A. Curtis, "Electrical Signature Analysis Applications For Non-Intrusive Automotive Alternator Diagnostics," Technology Showcase: Integrated Monitoring, Diagnostics And Failure-Prevention. Proceedings of A Joint Conference, Mobile, Alabama, April 22-26, 1996.

[8] W. Eversmann, S. Burnsa, S. Pekarek, Hua Bai, J. Tichenor," Noise Generation Mechanisms In Claw Pole Alternators," Journal Of Sound And Vibration 283 (2005) 369-400.

[9] Mohammad Reza Asadi Asad Abad, Ashkan Moosavian, And Meghdad Khazaee," Wavelet Transform And Least Square Support Vector Machine For Mechanical Fault Detection Of An Alternator Using Vibration Signal," Journal Of Low-Frequency Noise, Vibration And Active Control 2016, Vol. 35(1) 52-63.

[10] P. A. Vladimirovich, "Fault diagnosis in automotive alternators based on the output voltage parameters," International Conference on Electrotechnical Complexes and Systems (ICOECS), Ufa, Russia, 2019, pp. 1-5, DOI: 10.1109/ICOECS46375.2019.8949994.

[11] A. Susanto, S.Q. Yusuf, A. Hamid, S. Subekti, "Implementation Of Frequency Response Function On Tapper Bearing Maintenance", Sinergi, V. 23, N. 2, 2019.

[12] O.D. Mohamad, M. Rantatalo, "Dynamic Response And Time-Frequency Analysis For Gear Tooth Crack Detection", Mechanical System And Signal Processing, V. 66-67, Pp. 612-624, Jan. 2016.

[13] I. Y. Shen, and E. M. Ladd, "Estimating Bearing Coefficients Of Fluid-Dynamic Spindle Motors Using Sub-Resonant Frequency Response," 2010 Apmrc, Singapore, 2010, Pp. 1-2

[14] R. V. Daniel, S. A. Siddhappa, S.A., Gajanan, S.B., "Effect Of Bearing On Vibration In Rotating Machinery", In IOP Conf. Series: Materials Science And Engineering: International Conference On Material Alloys And Experimental Mechanics, India, 2017.

[15] M. Ikhsan, A. P. Monika, D. O. Rio, H. Abdul, S. Subekti," Analisis Getaran Tapered Roller Bearing Pada Turbine Propeller Sebelum dan Sesudah Pelumasan (Oli \& Grease) Dengan Metode Bump Test," Barometer, Volume 5 No.2, Juni 2020, 277-281.

[16] Subekti, "Studying The Dynamic Characteristics To Lengthen The Operating Life For A Diesel Engine Using Frequency Response Function (Frf) Measurement", Sinergi, V. 22, N. 3, 2018.

[17] B. D. Effendi, Subekti, A. Hammid, "Karakteristik Dinamik Disc Brake Daihatsu Sigra 1200 Cc Dengan Metode Bump Test", Flywheel: Jurnal Teknik Mesin Untirta, V. 5, N. 1, Pp. 14-19, April 2019.

[18] S. Subekti, A. Hamid, B. D. Effendy, A. W. Biantoro, "Inspecting A Bump Test In The Maintenance Of A 1200-Cc Daihatsu Sigra Disc Brake", Sinergi, V. 23, N. 3, Pp. 191-198, Okt. 2019.

[19] A. W. Biantoro, H. Maryanto, A. K. Hidayanto, A. Hamid, "The Investigation Of End Mill Feeds On Cnc Router Machine Using Vibration Method", Sinergi, V. 24, N. 2, Pp. 117-124, June 2020.

[20] H. Sangian, D. A. Rahman, R. Rudiwanto, S. Subekti, A. Hamid, "Analisis Getaran Pada Screw Compressor Akibat Pengaruh Putaran Rotor", Rekayasa Mesin, V. 11, N. 2, Pp. 267-275, 2020.

[21] S. Subekti, M. N. Hidayat, B. D. Efendi, A. Hamid, A. Murwanto, "Hilbert Transform Analyzer For Mechanical Fault Detection Of Vehicle Alternators", Automotive Experiences, V. 3, N.3, Pp. 89-95, 2020.

[22] F. Homaei, S. Shojaee, G. G. Amiri, "Multiple-Structural Damage Detection Using Measured Frequency Response Function", Iranian Journal of Structural Engineering. V. 2, N.1, Pp. 13-18, 2015.

[23] R. M. Lin, "Modeling, Detection, And Identification Of Flexural Crack Damages In Beam Using Frequency Response Function", Meccanica, V. 51, N. 9, Pp. 2027-2044, 2015.

[24] A. B. Ghatwai, S. V. Chaitanya, S. B. Phadke, "Frequency Response Function Measurements Of Disc And Drum Brake With Its Verification By Cae", International Research Journal Of Engineering And Technology, V.3, N. 5, Pp. 2223-2228, 2016. 